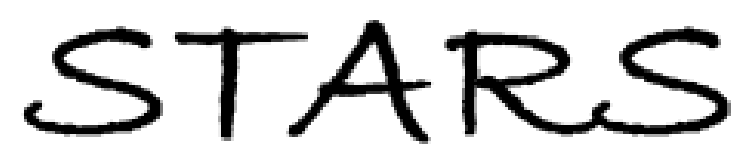

University of Central Florida

STARS

PRISM: Political \& Rights Issues \& Social Movements

$1-1-1947$

\title{
The coming American revolution
}

James Patrick Cannon

Find similar works at: https://stars.library.ucf.edu/prism

University of Central Florida Libraries http://library.ucf.edu

This Book is brought to you for free and open access by STARS. It has been accepted for inclusion in PRISM: Political \& Rights Issues \& Social Movements by an authorized administrator of STARS. For more information, please contact STARS@ucf.edu.

\section{Recommended Citation}

Cannon, James Patrick, "The coming American revolution" (1947). PRISM: Political \& Rights Issues \& Social Movements. 11.

https://stars.library.ucf.edu/prism/11

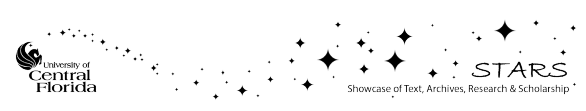




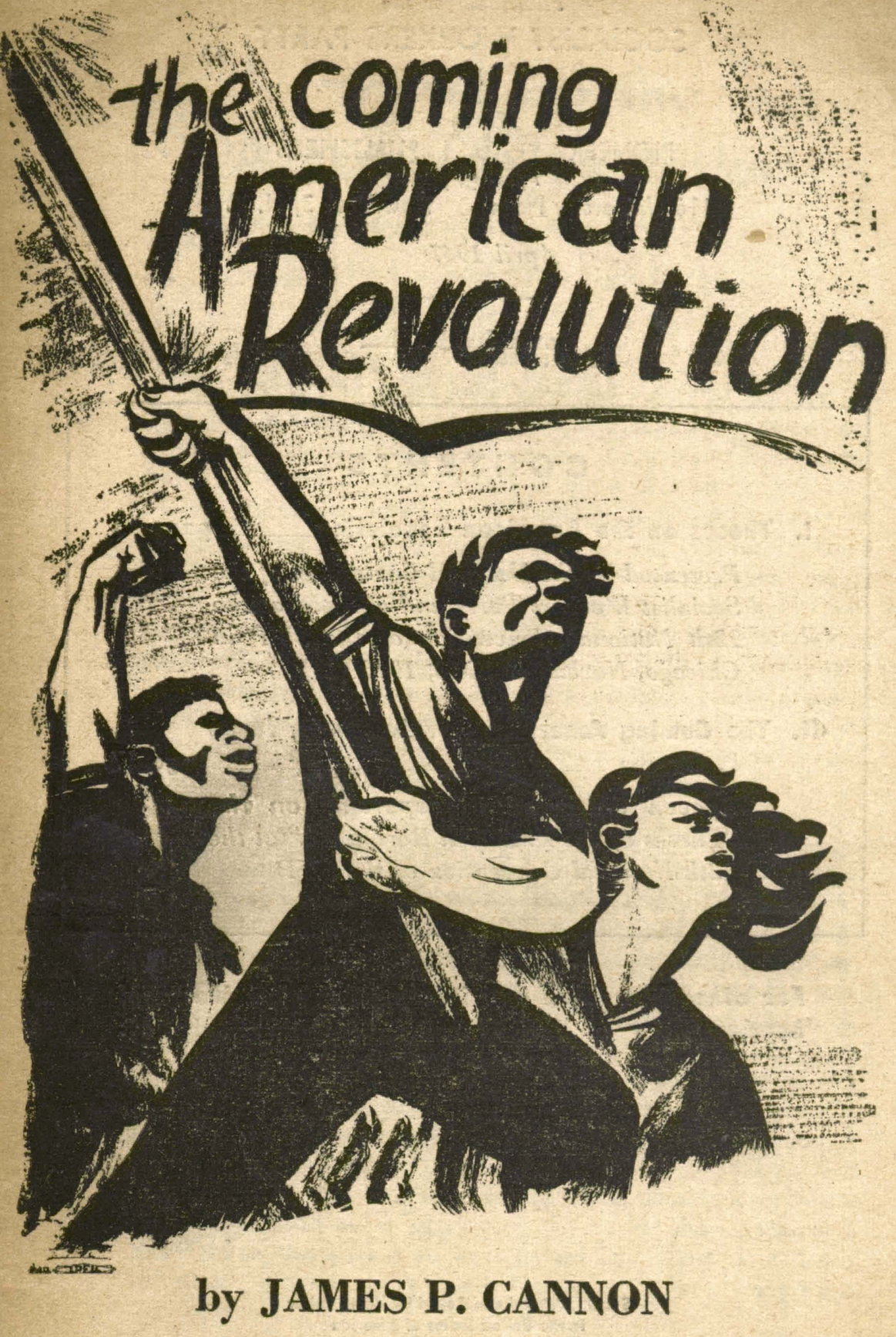

PIONEER PUBLISHERS

10. 


\section{Published for the SOCIALIST WORKERS PARTY}

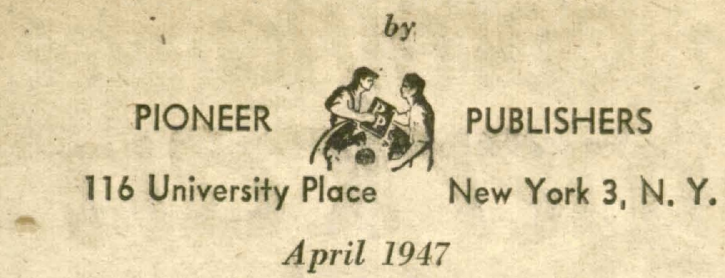

Cover by J. Thal

\section{CONTENTS}

I. Theses on the American Revolution page 9

Presented by the National Committee of the Socialist Workers Party and adopted at the 12th National Convention of the SWP in Chicago, November 15-18, 1946

II. The Coming American Revolution, by James

P. Cannon page 17

Speech delivered in reporting on the "Theses of the American Revolution" at the 12th National Convention of the SWP.

For other literature and information, visit the local headquarters of the Socialist Workers Party at: 


\section{Theses on the}

\section{American Revolution}

\section{Adopted by the Twelfth National Convention of the Socialist Workers Party}

The United States, the most powerful capitalist country in history, is a component part of the world capitalist system and is subject to the same general laws. It suffers from the same incurable diseases and is destined to share the same fate. The

- overwhelming preponderance of American imperialism does not exempt it from the decay of world capitalism, but, on the contrary, acts-to involve it ever more deeply, inextricably and hopelessly. U. S. capitalism can no more escape from the revolutionary consequences of world capitalist decay than the older European capitalist powers. The blind alley in which world capitalism has arrived, and the U. S. with it, excludes a new organic era of capitalist stabilization. The dominant world position of American imperialism now accentuates and aggravates the death agony of capitalism as a whole.

II

American imperialism emerged victorious from the Second World War not merely over its German and Japanese rivals but also over its "democratic" Allies, especially Great Britain. Today Wall Street unquestionably is the dominant world imperialist center. Precisely because it has issued from the war vastly strengthened in relation to all its capitalist rivals, U. S. imperialism seems indomitable. So overpowering in all fieldsdiplomatic, military, commercial, financial and industrial-is Wall Street's preponderance that consolidation of its world hegemony seems to be within easy reach. Wall Street hopes to inaugurate the so-called "American Century."

In reality, the American ruling class faces more insurmountable obstacles in "organizing the world" than confronted the German bourgeoisie in its repeated and abortive attempts to attain a much more modest goal, namely: "organizing Europe."

The meteoric rise of U. S. imperialism to world supremacy comes too late. Moreover, American imperialism rests increas- 
ingly on the foundations of world economy, in sharp contrast to the situation prevailing before the First World War, when it rested primarily on the internal market-the source of its previous successes and equilibrium. But the world foundation is today shot through with inseluble contradictions; it suffers from chronic dislocations and is mined with revolutionary powder kegs.

American capitalism, hitherto only partially involved in the death agony of capitalism as a world system, is henceforth subject to the full and direct impact of all the forces and contradictions that have debilitated the old capitalist countries of Europe.

The economic prerequisites for the Socialist revolution are fully matured in the U.S. The political premises are likewise far more advanced than might appear on the surface.

\section{III}

The U. S. emerged from the Second World War, just as it did in 1918-as the strongest part of the capitalist world. But here ends the resemblance in the impact and consequences of the two wars upon the country's economic life. For in other major aspects the situation has in the meantime drastically altered.

In 1914-18 continental Europe was the main theater of war; the rest of the world, especially the colonial countries, was left virtually untouched by the hostilities. Thus, not only sections of continental Europe and England but the main framework of the world market itself remained intact. With all its European competitors embroiled in the war, the way was left clear for American capitalism to capture markets.

More than this, during the First World War capitalist Europe itself became a vast market for American industry and agriculture. The American bourgeoisie drained Europe of her accumulated wealth of centuries and supplanted their Old World rivals in the world market. This enabled the ruling class to convert the U. S. from a debtor into the world's banker and creditor, and simultaneously to expand both the heavy (capital goods) and the light (consumer goods) industries. Subsequently this wartime expansion permitted the fullest possible development of this country's domestic market. Finally, not merely did the American bourgeoisie make vast profits from the war but the country as a whole emerged much richer. The relatively cheap price of imperialist participation in World War I (only a few score billion dollars) was covered many times over by the accruing economic gains.

Profoundly different in its effects is the Second World War. 
This time only the Western hemisphere has been left untouched militarily. The Far East, the main prize of the war, has been subjected to a devastation second only to that suffered by Germany and Eastern Europe. Continental Europe as well as Eng. land have been bankrupted by the war. The world market has been completely disrupted. Thus culminated the process of shrinking, splintering and undermining that went on in the interval between the two wars (the withdrawal of one-sixth of the world - the USSR-from the capitalist orbit, the debasement of currency systems, the barter methods of Hitlerite Germany, Japan's inroads on Asiatic and Latin American markets, England's Empire Preference System, etc., etc.).

Europe, which defaulted on all its prior war and post-war debts to the U.S., this time served not as an inexhaustible and highly profitable market, but as a gigantic drain upon the wealth and resources of this country in the shape of LendLease, over-all conversion of American economy for wartime production, huge mobilization of manpower, large-scale casualties, and so on.

With regard to the internal market, the latter, instead of expanding organically as in 1914-18, experienced in the course of the Second World War only an artificial revival based on war expenditures.

While the bourgeoisie has been fabulously enriched, the country as a whole has become much poorer: the astronomic costs of the war will never be recouped.

In sum, the major factors that once served to foster and fortify American capitalism either no longer exist or are turning into their opposites.

\section{iv}

The prosperity that followed the First World War, which was hailed as a new capitalist era refuting all Marxist prognostications, ended in an economic eatastrophe. But even this shortlived prosperity of the Twenties was based on a combination of circumstances which cannot and will not recur again. In addition to the factors already listed, it is necessary to stress: (1) that American capitalism had a virgin continent to exploit; (2) that up to a point it had been able to maintain a certain balance between industry and agriculture; and (3) that the main base of capitalist expansion had been its internal market. So long as these three conditions existed-although they were already being undermined -it was possible for U.S. capitalism to maintain a relative stability.

The boom in the Twenties nourished the myth of the permanent stability of American capitalism, giving rise to pompous 
and hollow theories of a "new capitalism," "American exceptionalism," the "American dream," and so forth and so on.

The illusions about the possibilities and future of American capitalism were spread by the reformists and all other apologists for the ruling class not only at home but abroad. "Americanism" was the gospel of all the misleaders of the European and American working class.

What actually happened in the course of the fabulous prosperity of the Twenties was that under these most favorable conditions, all the premises for an unparalleled economic catastrophe were prepared. Out of it came a chronic crisis of American agriculture. Out of it came a monstrous concentration of wealth in fewer and fewer hands. Correspondingly, the rest of the population became relatively poorer. Thus, while in the decade of $1920-30$, industrial productivity increased by 50 per cent, wages rose only 30 per cent. The workers were able to buy -in prosperity-proportionately less than before.

The relative impoverishment of the American people is likewise mirrored in national wealth statisties. By 1928 the workers' share of the national wealth had dropped to 4.7 per cent; while the farmers retained only 15.4 per cent. At the same time, the bourgeoisie's share of the national wealth had risen to 79.9 per cent, with most of it falling into the hands of Sixty Families and their retainers.

The distribution of national income likewise expressed this monstrous disproportion. In 1929, at the peak of prosperity, 36,000 families had the same income as 11 million "lowerbracket" families.

This concentration of wealth was a cardinal factor in limiting the absorbing capacity of the internal market.

Compensating external outlets for agriculture and industry could not be found in a constricting world market.

Moreover, the need to export raw materials and agricultural products tended to further unbalance American foreign trade. This inescapably led to a further dislocation of the world market, whose participants were debtor countries, themselves in need of selling more than they bought in order to cover payments on their debts, largely owed to the U. S.

While appearing and functioning in the role of stabilizers of capitalism, the American imperialists were thus its greatest disrupters both at home and abroad. The U. S. turned out to be the main source of world instability, the prime aggravator of imperialist contradictions.

In the interim between the two wars this manifested itself most graphically in the fact that all economic convulsions began in the Republic of the Dollar, the home of "rugged indiv- 
idualism." This was the ease with the first post-war erisis of 1920-21; this was repeated eight years later when the dispro. portion between agriculture and industry reached the breaking point and when the internal market had beeome saturated owing to the impoverishment of the people at one pole and the aggrandizement of the monopolists at the other. The Great American Boom exploded in a crisis which shattered the economic foundations of all eapitalist countries.

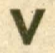

The economic crisis of 1929 was not a cyclical crisis such as periodically accompanied organic capitalist development in the past, leading to new and higher productive levels. It was a major historieal crisis of eapitalism in decay, which could not be overcome through the "normal" channels; that is to say, through the blind interplay of the laws governing the market.

Production virtually came to a standstill. National income was cut into less than half, plummeting from 81 billion dollars in 1929 to 40 billion dollars in 1932. Industry and agriculture sagged. The army of unemployed swelled tenfold "normal," reaching the dizzy figure of 20 million. According to official estimates, based on 1929 averages, the losses in the years 1930 . 38 amounted to 43 million man-years of labor, and 133 billion dollars of national income.

By 1939 the national debt soared to 40 billion dollars, or 14. billion more than the highest point at the end of the First World War. The number of unemployed kept hovering at 10 million. Industry and agriculture stagnated. The foreign trade of the U.S. in a reduced world market fell to less than half of its "normal" peacetime share.

What all these figures really express is the fearsome degradation of living standards of the workers and the middle class, and the outright pauperization of the "underprivileged onethird" of the population. The wafer-thin layer of monopolists, naturally, did not suffer at all, but on the contrary utilized the crisis in order to gobble up even a larger share of the country's wealth and resources.

The bourgeoisie saw no way out of the crisis. They had no way out. They and their regime remained the main obstacle in the way not only of domestic but of world recovery. In its downward plunge, the American bourgeoisie dragged the rest of the capitalist world with it, and kept it down.

Decisive is the fact that despite all the "pump-priming," "brain-trusting," and emergency "reforms," American capitalism was incapable of solving the crisis. The partial upswing of 1934-37 proved to be temporary and passing in character. 
The precipitous drop that occurred in 1937 revealed the abyss facing American capitalism. The threatening new downward plunge was cut off only by the huge expenditures made in preparation for the Second World War.

Only the war temporarily resolved the economic crisis which had lasted in both hemispheres for ten years. The grim reality, however, is that this "solution" has solved exactly nothing. Least of all did it remove or even mitigate a single one of the basic causes for the crisis of 1929.

\section{VI}

The basis of the current American post-war prosperity is the artificial expansion of industry and agriculture through unprecedented government spending which is swelling constantly the enormous national debt. In its fictitious character the war and post-war boom of the early Forties far exceeds the orgy engaged in by European capitalism during 1914-18 and the immediate post-war years.

The diversion of production into war industry on an unheard-of scale resulted in temporary shortages of consumer goods. The home and foreign markets seemed to acquire a new absorbing capacity. Universal scarcities and war havoc are acting as temporary spurs to production, especially in the consumers' goods field.

Over-all there is, however, the universal impoverishment, the disrupted economic, fiscal and governmental systemscoupled with the chronic diseases and contradictions of capitalism, not softened but aggravated by the war.

If we multiply the condition in which European capitalism, with England at its head, emerged from the First World War by ten times and in some instances a hundred times-because of the vaster scale of the consequences of World War II-then we will arrive at an approximation of the actual state of American capitalism.

Every single factor underlying the current "peacetime" prosperity is ephemeral. This country has emerged not richer from the Second World War as was the case in the Twenties, but poorer - in a far more impoverished world. The disproportion between agriculture and industry has likewise increased tremen, dously, despite the hot-house expansion of agriculture. The concentration of wealth and the polarization of the American population into rich and poor has continued at a forced pace.

The basic conditions that precipitated the 1929 crisis when American capitalism enjoyed its fullest health, not only persist but have grown more malignant. Once the internal market is again saturated, no adequate outlet can be hoped for in the 
unbalanced world market. The enormously augmented productive capacity of the U.S. collides against the limits of the world market and its shrinking capacity. Ruined Europe herself needs to export. So does the ruined Orient, whose equilibrium has been ruptured by the shattering of Japan, its most advanced sector.

Europe is in dire need of billions in loans. In addition to Lend-Lease, Wall Street has already pumped almost 5 billion dollars in loans into England; almost 2 billions into France; and smaller sums into the other satellite countries of Western Europe-without, however, achieving any semblance of stabilization there. Bankrupt capitalist Europe remains both a competitor on the world market and a bottomless drain. The Orient, too, needs loans, especially China, which, while in the throes of civil war, has already swallowed up as many American dollars as did Germany in the early Twenties.

At home, the explosive materials are accumulating at a truly American tempo. Carrying charges on the huge national debt; the astronomic military "peacetime" budget (18.5 billion dollars for this year); the inflation, the "overhead expenditures" of Wall Street's program of world domination, etc., etc.-all this can come from one source and one only: national income. In plain words, from the purchasing power of the masses. Degradation of workers' living conditions and the pauperization of the farmers and the urban middle class - that is the meaning of Wall Street's program.

\section{VII}

The following conclusion flows from the objective situation: U.S. imperialism which proved incapable of recovering from its crisis and stabilizing itself in the ten-year period preceding the outbreak of the Second World War is heading for an even more catastrophic explosion in the current post-war era. The cardinal factor which will light the fuse is this: The home market, after an initial and artificial revival, must contract. It cannot expand as it did in the Twenties. What is really in store is not unbounded prosperity but a short-lived boom. In the wake of the boom must come another crisis and depression which will make the 1929-32 conditions look prosperous by comparison.

\section{VIII}

The impending economic paroxysms must, under the existing conditions, pass inexorably into the social and political crisis of American capitalism, posing in its course pointblank the 
question of who shall be the master in the land. In their mad drive to conquer and enslave the entire world the American monopolists are today preparing war against the Soviet Union. This war program, which may be brought to a head by a crisis or the fear of a crisis at home, will meet with incalculable obstacles and difficulties. A war will not solve the internal difficulties of American imperialism but will rather sharpen and complicate them. Such a war will meet with fierce resistance not only by the peoples of the USSR, but also by the European and colonial masses who do not want to be the slaves of Wall Street. At home the fiercest resistance will be generated. Wall Street's war drive, aggravating the social crisis, may under certain conditions actually precipitate it. In any case, another war will not cancel out the socialist alternative to capitalism but only pose it more sharply.

The workers' struggle for power in the U.S. is not a perspective of a distant and hazy future but the realistic program of our epoch.

\section{IX}

The revolutionary movement of the American workers is an organic part of the world revolutionary process. The revolution * ary upheavals of the European proletariat which lie ahead will complement, reinforce and accelerate the revolutionary developments in the U.S. The liberationist struggles of the colonial peoples against imperialism which are unfolding before our eyes will exert a similar influence. Conversely, each blow dealt by the American proletariat to the imperialists at home will stimulate, supplement and intensify the revolutionary strug. gles in Europe and the colonies. Every reversal suffered by imperialism anywhere will, in turn, produce ever greater repercussions in this country, generating such speed and power as will tend to reduce all time-intervals both at home and abroad.

\section{$\mathbf{x}$}

The role of America in the world is decisive. Should the European and colonial revolutions, now on the order of the day, precede in point of time the culmination of the struggle in the U.S., they would immediately be confronted with the necessity of defending their conquests against the economic and military assaults of the American imperialist monster. The ability of the victorious insurgent peoples everywhere to maintain themselves would depend to a high degree on the strength and fighting capacity of the revolutionary labor movement in America. The American workers would then be obliged to come 
to their aid, just as the Western European working class came to the aid of the Russian Revolution and saved it by blocking full-scale imperialist military assaults upon the young Workers Republie.

But even should the revolution in Europe and other parts of the world be once again retarded, it will by no means signify a prolonged stabilization of the world capitalist system. The issue of socialism or capitalism will not be finally decided until it is decided in the U.S. Another retardation of the proletarian revolution in one country or another, or even one continent or another, will not save American imperialism from its proletarian nemesis at home. The decisive battles for the Communist future of mankind will be fought in the U.S.

The revolutionary victory of the workers in the U.S. will seal the doom of the senile bourgeois regimes in every part of our planet, and of the Stalinist bureaucracy, if it still exists at the time. The Russian Revolution raised the workers and colonial peoples to their feet. The American Revolution with its hundredfold greater power will set in motion revolutionary forces that will change the face of our planet. The whole Western Hemisphere will quickly be consolidated into the Socialist United States of North, Central and South America. This invincible power, merging with the revolutionary movements in all parts of the world, will put an end to the outlived capitalist system as a whole, and begin the grandiose task of world reconstruction under the banner of the Socialist United States of the World.

\section{XI}

Whereas the main problem of the workers in the Russian Revolution was to maintain their power once they had gained it, the problem in the United States is almost exclusively the problem of the conquest of power by the workers. The conquest of power in the United States will be more difficult than it was in backward Russia, but precisely for that reason it will be much easier to consolidate and secure.

The dangers of internal counter-revolution, foreign intervention, imperialist blockade and bureaucratic degeneration of a privileged labor caste-in Russia all of these dangers stemmed from the numerical weakness of the proletariat, the age-long poverty and backwardness inherited from Czarism, and the isolation of the Russian Revolution. These dangers were in the final analysis unavoidable there.

These dangers scarcely exist in the U.S. Thanks to the overwhelming numerical superiority and social weight of the proletariat, its high cultural level and potential; thanks to the country's vast resources, its productive capacity and preponder- 
ant strength on the world arena, the victorious proletarian revolution in the U.S., once it has consolidated its power, will be almost automatically secured against capitalist restoration either by internal counter-revolution or by foreign intervention and imperialist blockade.

As for the danger of bureaucratic degeneration after the revolutionary victory - this can only arise from privileges which are in turn based on backwardness, poverty and universal searcities. Such a danger could have no material foundation within the U.S. Here the triumphant Workers' and Farmers' Government would from the very beginning be able to organize socialist production on far higher levels than under capitalism, and virtually overnight assure such a high standard of living for the masses as would strip privileges in the material sense of any serious meaning whatever. Mawkish speculations concerning the danger of bureaucratic degeneration after the victorious revolution serve no purpose except to introduce skepticism and pessimism into the ranks of the workers' vanguard, and paralyze their will to struggle, while providing fainthearts and snivelers with a convenient pretext for running away from the struggle. The problem in the U.S. is almost exclusively the problem of the workers' conquest of political power.

\section{XII}

In the coming struggle for power the main advantages will be on the side of the workers; with adequate mobilization of their forces and proper direction the workers will win. If one wishes to deal with stern realities and not with superficial appearances, that is the only way to pose the question. The American capitalist class is strong, but the American working class is stronger.

The numerical strength and social weight of the American working class, greatly increased by the war, is overwhelming in the country's life. Nothing can stand up against it. The productivity of American labor, likewise greatly increased in wartime, is the highest in the world. This means skill, and skill means power.

The American workers are accustomed to the highest living and working standards. The widely-held view that high wages are a conservatizing factor tending to make workers immune to revolutionary ideas and actions, is one-sided and false. This holds true only under conditions of capitalist stability where the relatively high standard of living can be maintained and even improved. This is excluded for the future, as our whole analysis has shown. On the other hand, the workers react most 
sensitively and violently to any infringement upon their living standards. This has already been demonstrated by the strike waves in which great masses of "conservative" workers have resorted to the most militant and radical course of action. In the given situation, therefore, the relatively high living standard of the American workers is a revolutionary and not, as is commonly believed, a conservatizing factor.

The revolutionary potential of the class is further strengthened by their traditional militancy coupled with the ability to react almost spontaneously in defense of their vital interests, and their singular resourcefulness and ingenuity (the sitdown strikes!).

Another highly important factor in raising the revolutionary potential of the American working class is its greatly increased cohesiveness and homogeneity-a transformation accomplished in the last quarter of a century.

Previously, large and decisive sections of the proletariat in the basic industries were recruited by immigration. These foreign-born workers were handicapped and divided by language barriers, treated as social pariahs and deprived of citizenship and the most elementary civil rights. All these circumstances appeared to be insuperable barriers in the way of their organization and functioning as a united labor force. In the intervening years, however, these foreign-born workers have been assimilated and "Americanized." They and their sons today constitute a powerful, militant and articulate detachment of the organized labor movement.

An equally significant and profound development is represented by the transformation that has taken place in the position occupied by the Negroes. Formerly barred and deprived of the rights and benefits of organization by the dominant reactionary craft unions and, on the other hand, regarded and sometimes utilized by the employers as a reserve for strikebreaking purposes, masses of Negroes have since the twenties penetrated into the basic industries and into the unions. Not less than two million Negroes are members of the CIO, AFL and independent unions. They have demonstrated in the great strike struggles that they stand in the front lines of progressiveness and militancy.

The American workers have the advantage of being comparatively free, especially among the younger and most militant layers, from reformist prejudices. The class as a whole has not been infected with the debilitating poison of reformism, either of the classic "Socialist" variety or the latter-day Stalinist brand. As a consequence, once they proceed to action, they more readily accept the most radical solutions. No important section of the class, let alone the class as a whole, has been demoralized 
by defeats. Finally, this young and mighty power is being drawn into the decisive phases of the class struggle at a tempo that creates unparalleled premises for mass radicalization.

\section{XIII}

Much has been said about the "backwardness" of the American working class as a justification for a pessimistic outlook, the postponement of the socialist revolution to a remote future and withdrawal from the struggle. This is a very superficial view of the American workers and their prospects.

It is true that this class, in many respects the most advanced and progressive in the world, has not yet taken the road of independent political action on a mass scale. But this weakness can be swiftly overcome. Under the compulsion of objective necessity not only backward peoples but backward classes in advanced countries find themselves driven to clear great distances in single leaps. As a matter of fact, the American working class has already made one such leap which has advanced it far ahead of its old positions.

The workers entered the 1929 crisis as an unorganized, atomized mass imbued with illusions concerning "rugged individualism," "private initiative," "free enterprise," "the American Way," etc., etc. Less than 10 per cent of the class as a whole was organized on the trade union field (fewer than 3 million out of 33 million in 1929). Moreover, this thin layer embraced primarily the highly skilled and privileged workers, organized in antiquated craft unions. The main and most decisive section of the workers knew unionism only as "company unionism," remaining without the benefit, the experience and even the understanding of the most elementary form of workers' organization - the trade union. They were regarded and treated as mere raw-material for capitalist exploitation, without rights or protection or any security of employment.

As a consequence, the 1929 crisis found the working class helpless and impotent. For three years the masses remained stunned and disoriented by the disaster. Their. resistance was extremely limited and sporadic. But their anger and resentment accumulated. The next five years (1933-37), coincident with a partial revival of industry, witnessed a series of gigantic clashes, street fights and sit-down strikes-an embryonic civil war-the end result of which was a leap, a giant leap, for millions of workers from non-existence as an organized force to trade union consciousness and organization. Once fairly started, the movement for unionism snow-balled, embracing today almost 15 million in all the basic industries. 
In one leap-in a brief decade-the American workers attained trade-union consciousness on a higher plane and with mightier organizations than in any other advanced country. In the study and analysis of this great transformation, rather than in vapid ruminations over the "backwardness" of the American workers, one can find the key to prospective future developments. Under the impact of great events and pressing necessities the American workers will advance beyond the limits of trade unionism and acquire political class consciousness and organization in a similar sweeping movement.

\section{XIV}

The decisive instrument of the proletarian revolution is the party of the class conscious vanguard. Failing the leadership of such a party, the most favorable revolutionary situations, which arise from the objective circumstances, cannot be carried through to the final victory of the proletariat and the beginnings of planned reorganization of society on socialist foundations. This was demonstrated most conclusively - and positively-in the 1917 Russian Revolution. This same principled lesson derives no less irrefutably - even though negatively - from the entire world experience of the epoch of wars, revolutions and colonial uprisings that began with the outbreak of the First World War in 1914.

However, this basic conclusion from the vast and tragic experience of the last third of a century, can be and has been given a reactionary interpretation by a school of neo-revision. ism, represented by the ideologues, philosophers and preachers of prostration, capitulation and defeat. They say in effect: "Since the revolutionary party is small and weak it is idle to speak of revolutionary possibilities. The weakness of the party changes everything." The authors of this "theory" reject and repudiate Marxism, embracing in its place the subjective school of sociology. They isolate the factor of the revolutionary party's relative numerical weakness at a particular moment from the totality of objective economic and political developments which creates all the necessary and sufficient conditions for the swift growth of the revolutionary vanguard party.

Given an objectively revolutionary situation, a proletarian party-even a small one-equipped with a precisely worked out Marxist program and firm cadres can expand its forces and come to the head of the revolutionary mass movement in a comparatively brief span of time. This too was proved conclusively-and positively-by the experiences of the Russian Revolution in 1917. There the Bolshevik Party, headed by Lenin and Trotsky, bounded forward from a tiny minority, just emerging 
from underground isolation in February to the conquest of power in October-a period of nine months.

Numerical weakness, to be sure, is not a virtue for a revolutionary party but a weakness to be overcome by persistent work and resolute struggle. In the U.S. all the conditions are in the process of unfolding for the rapid transformation of the organized vanguard from a propaganda group to a mass party strong enough to lead the revolutionary struggle for power.

\section{XV}

The hopeless contradictions of American capitalism, inextricably tied up with the death agony of world capitalism, are bound to lead to a social crisis of such catastrophic proportions as will place the proletarian revolution on the order of the day.

In this crisis, it is realistic to expect that the American workers, who attained trade-union consciousness and organization within a single decade, will pass through another great transformation in their mentality, attaining political consciousness and organization. If in the course of this dynamic development a mass labor party based on the trade unions is formed, it will not represent a detour into reformist stagnation and futility, as happened in England and elsewhere in the period of capitalist ascent. From all indications, it will rather represent a preliminary stage in the political radicalization of the American workers, preparing them for the direct leadership of the revolutionary party.

The revolutionary vanguard party, destined to lead this tumultuous revolutionary movement in the U.S., does not have to be created. It already exists, and its name is the Socialist Workers PARTY. It is the sole legitimate heir and continuator of pioneer American Communism and the revolutionary movements of the American workers from which it sprang. Its nucleus has already taken shape in three decades of unremitting work and struggle against the stream. Its program has been hammered out in ideological battles and successfully defended against every kind of revisionist assault upon it. The fundamental core of a professional leadership has been assembled and trained in the irreconcilable spirit of the combat party of the revolution.

The task of the Socialist Workers Party consists simply in this: To remain true to its program and banner; to render it more precise with each new development and apply it correctly in the class struggle; and to expand and grow with the growth of the revolutionary mass movement, always aspiring to lead it to victory in the struggle for political power. 


\section{The Coming \\ American Revolution}

By James P. Cannon

We have undertaken as our central task at this 12th Convention of the Socialist Workers Party to analyze the present stage in the development of United States imperialism as it emerged from the Second World War-and its further perspectivesand to draw the necessary conclusions from this analysis.

In our main thesis we deal exclusively with the perspectives of the American Revolution. Secondary questions of tactics, and even of strategy, are left for consideration under another point on the agenda after we have discussed and decided the main question of perspective.

\section{Why Are the Theses on Perspectives Needed Now?}

The question might be asked: Why are the theses on perspectives needed now? In order for the party to see clearly on the road ahead it is necessary to have a main orientation and a long-range view of future developments. The theses we have presented are needed at the present moment for a number of reasons.

First, the whole Trotskyist concept of our epoch as the epoch of revolutions, has been challenged by a new school of revisionists of Marxism. What answer do we give to this challenge, with specific reference to the United States of America?

What conclusions do we draw from the war and its consequences; from the new power of American imperialism; from the postwar prosperity; and from the retardation of the European revolution? What conclusions do we draw from these great events for the conduct of our own work and for our own future outlook in the United States?

Secondly, what shall we say to our co-thinkers in other lands about revolutionary prospects in the United States? They are surely waiting to hear from our convention on this question, for it is of the most vital and decisive importance for them. This applies to the workers of Europe, but not only to them. 
It applies to the workers of Russia, of South and Central America, of China, Japan, Asia as a whole, India - in fact, to the workers of the whole world which lies today under the shadow of American imperialism.

And finally, what shall the party teach the new members who today are streaming into our ranks by hundreds and who will come to us tomorrow in thousands? What shall we tell them concretely about the prospects of the revolution in the United States? That is what they want to know above everything else.

Our document undertakes to give straight answers to all these questions.

Another question may well be asked: What is new in the "Theses on the American Revolution" presented by the National Committee?

In one sense it can be said that nothing is new; for all our work has been inspired by, and all our struggles with opportunist tendencies have been derived from, a firm confidence on our part in the coming victory of the American workers.

In another sense it can be said that everything is new; for in the theses of the National Committee on the American Revolution we are now stating, explicitly and concretely, what has always been implied in our fights with opportunist organizations, groups and tendencies over questions which were derivative from this main outlook of ours.

That has been the underlying significance of our long struggle to build a homogeneous combat party. That has been the meaning of our stubborn and irreconcilable fight for a single program uniting the party as a whole; for a democratic and centralized and disciplined party with a professional leadership; for principled politics; for the proletarianization of the party composition; for the concentration of the party on trade union work ("trade-unionization of the party"); and, if I may say so without being misunderstood, for its "Americanization." All of this derived from our concept of the realism of revolutionary prospects in America, and of the necessity to create a party with that perspective in mind.

In short, we have worked and struggled to build a party fit to lead a revolution in the United States. At the bottom of all our conceptions was the basic conception that the proletarian revolution is a realistic proposition in this country, and not merely a far-off "ultimate goal," to be referred to on ceremonial occasions.

I say that is not new. In fact, it has often been expressed by many of us, including Trotsky, in personal articles and speeches. But only now, for the first time, has it been incorporated in a 
programmatic document of the party. That's what is new in our "Theses on the American Revolution." We are now stating explieitly what before was implied.

For the first time, the party as a party is posing concretely the fundamental question of the perspectives of the American Revalution.

You will note in your reading of the theses that secondary questions of tactics and even of strategy, with all their importance, are left out. And this is not by accident or negligence, but by design. The theses deal only with analysis and perspectives - and these only in the broadest sense-because. that is the fundamental basis from which we proceed.

Tactical questions and even questions of great strategical importance-such as the alliance of the labor movement and the Negro people, the role of the returned war veterans, the relations between the workers and the poor farmers and the urban petty-bourgeoisie, the questions of fascism and of the labor party-these questions with all their great subordinate importance are left out of the main theses for separate consideration in other documents. They will be considered at another time in the convention, because the correct answer to all of them depends in reality on a correct answer to the main question of general perspective posed in the theses of the National Committee.

Of course, a general line, a general perspective, does not guarantee that one will always find the right answer to derivative questions, the secondary issues. But without such a general orientation, without this broad over-all ruling conception, it is quite. hopeless to expect to find one's way in tactical and strategical questions.

The theses have been criticized already by people who deal exclusively in "the small coin of concrete events." We have been criticized because we "do not mention concrete tasks" and "pose ne concrete problems."

That is true. But what is wrong with that procedure?

We are Marxists; and therefore we do not begin with the small questions, with the tactics, or even with the strategy. We first lay down the governing line from which the answers to the secondary questions derive.

Those who preoccupy themselves primarily with tactics reproach us for our procedure, and allege that it reveals the difference between their political method and ours. That is quite correct. We proceed from the fundamental to the secondary; they proceed by nibbling at the secondary questions in order to. undermine the fundamental concepts. There is indeed a difference in method. 
Our theses specifically outline the revolutionary perspectives in America and require the party to conduct and regulate all its daily activity in the light of these perspectives.

\section{Internationalism}

Our preoccupation at this convention with American affairs and American perspectives does not signify a departure on our part from the time-honored internationalism which has always distinguished our tendency. Rather, we are taking a step forward in the application of our internationalist concepts to American affairs. That means to bring them down from the realm of abstraction and give them flesh and blood.

We began in 1928 with a struggle for internationalism against the dogma of "socialism in one country" which had been imposed upon the Comintern and all its sections by the Stalinist revisionists. That was the most fundamental of all the principled questions which have shaped and guided the development of our movement in America for the past 18 years.

We said then, and we still believe, that the modern world is an economic unit; and that not a single important social problem-and certainly not the most important problem, the socialist reorganization of society-can be definitively solved on national grounds.

With the presentation of the theses of the National Committee on the perspectives of the American Revolution, we are adding a correlative idea to the following effect: It is no longer possible to speak seriously about the world socialist revolution without specifically including America in the program. Today that would be almost as utopian as was the theory of "socialism in one country" when it was first promulgated by Stalin for Russia in 1924.

This was always true, but it is truer now than ever in the light of the Second World War and its outcome. The United States has emerged from the war as the strongest power in the world, both economically and militarily. Our theses assert that the role of the United States in further world developments will be decisive in all respects.

If the workers in another country, or even in a series of other countries, take power before the revolutionary victory in the United States, they will have to defend themselves against the American colossus, armed to the teeth and counter-revolutionary to the core.

On the other hand, a revolutionary victory in the United States, signalizing the downfall of the strongest bastion of capitalism, would seal its doom on an international scale.

Or, in a third variant, if the socialist revolution should be 
defeated in other countries or even on other continents, and pushed back and retarded, we can still fight and win in the United States. And that would again revive the revolution everywhere else in the world.

The world situation makes it quite clear that platonic internationalism is decidedly out of date in this country. Internationalism, as the Trotskyists have conceived it, means first of all, international collaboration. But in our view this international collaboration must signify not only the discussion of the problems and tasks of co-thinkers in other countries-this is where platonic internationalism begins and ends-but also the solution of these problems, above all our own specific problems, in action. That is our conception of internationalism as we mean to apply it and as we have expressed it in the theses.

One-sided internationalism - preoccupation with far-off questions to the exclusion and neglect of the burning problems on one's own doorstep-is a form of escapism from the realities at home, a caricature of internationalism. This simple truth has not always been understood, and there are some people who do not understand it yet. But our party can justify its existence only if, beginning with an international program, it succeeds in applying this program to the conditions of American life and confirming it in action.

This presupposes first of all an attentive study of America and a firm confidence in its revolutionary perspectives. Those who are content with the role of commentators on foreign affairs - and it is surprising how many there are-or that of a Red Cross society to aid other revolutions in other countries, will never lead a revolution in their own country; and in the long run they will not be of much help to other countries either. What the other countries need from us, above everything else, is one small but good revolution in the United States.

Trotskyism - which is only another name for Bolshevism -is a world doctrine and concerns itself with all questions of world import. But let us not forget-or rather, let some of us begin to recognize for the first time-that America, the United States, is part of the world; in fact, its strongest and most decisive part, whose further development will be most fateful for the whole.

It is from this point of view that we deem it necessary now to outline more concretely and more precisely than before our estimation of American perspectives, and to concentrate on the preparation for them. When we speak of the "Americanization" of the party in this sense we are not speaking as vulgar nationalists-far from it-but as genuine internationalists of the deed as well as of the word. 


\section{The Objective Factors for the American Revolution}

Our theses on the perspectives of the American Revolution proceed in accord with the Marxist method and the Marxist tradition by analyzing and emphasizing first of all the objective factors that are making for the revolution. These are primary. These are fundamental. Any other approach than that which begins with the objective factors is unrealistie, mere wish-thinking utopianism, no matter how revolutionary-minded its proponents may be.

This characterization of unrealism applies also to the new revelation of those who have exalted the subjective factormeaning thereby the party and its strength or weakness at the given moment - to first place.

It would be incorrect, however, to add the supplementary qualification that these latter-day experts of the subjective factor, these latter-day revisionists, are "revolutionary-minded." They are unrealistic, but not revolutionary-minded, for they employ their new "theory" exclusively for the explanation of past defeats and anticipation and prediction of new ones. I don't see anything revolutionary about that.

Our theses pay due acknowledgement to the great strength of United States imperialism. Let no one accuse us of failing to give the American imperialist power its due. We paid due acknowledgement to it. This is correct and proper in a document which aims at scientific objectivity; for the might and resources of the Yankee colossus are so imposing in relation to all other countries, and in relation to anything that has ever been seen in the world before in the realm of material powerand have been so well advertised in the bargain - that no one could possibly overlook them.

But our theses-and here we demarcate ourselves from all those who are hypnotized by the superficial appearance of things - point out not only the strength of American imperialism but also its inherent weaknesses; the contradictions from which it cannot escape; and the new, even greater, power which it has created and which is destined to be its grave-digger-the American working class. That is also part of the American picture which has to be observed and noted if one wants to have a completely true and objectively formulated document.

A one-sided view of the American capitalist system-overestimation of its power and awe-stricken prostration before itis the source of many illusions. And these illusions, in turn, are the chief source of American labor opportunism in general; of the capitulation and treachery of the radical intellectuals 
en masse; of Stalinism; and of all varieties of reformism and Menshevism.

In considering the perspectives of the American capitalist system in general and of the present postwar prosperity in particular, we observe a peculiar and rather interesting anomaly. The capitalist masters of society, and their ideologues and economic experts, enter the new period with doubts and fears which they do not conceal; while the greatest confidence in the long life and good health of the present order of society in America is either openly expressed or tacitly implied by those who set themselves up as representatives of the workers-namely, the official leadership of the labor movements and the Mensheviks of all grades.

The American bourgeoisie entered the great boom of the Twenties with the exuberant confidence and enthusiasm of alchemists who had finally discovered the philosopher's stone which turns everything into gold. In that golden age of American capitalism a new school of bourgeois economists came from the colleges to proclaim the glad tidings that Marx had been refuted by Henry Ford; that American business genius had discovered the secret of full employment and permanent prosperity without interfering with the private ownership of the means of production, but on the contrary, strengthening it and aiding its concentration.

They continued to beat the drums on this theme up to the year, the month and even to the day when the stupendous myth of the Twenties was exploded in the stockmarket crash of 1929. The very week in which the whole structure came tumbling down, the most learned articles were published in the name of the most eminent college professors explaining that this prosperity was going to go higher and would continue endlessly.

It is true that the labor leaders and the Social Democrats. in this country and throughout the world were captivated by the myth of permanent prosperity in the Twenties and were enlisted in the great parade. But they only followed; they did not lead. The capitalists were in the lead, full of confidence and optimism in those days. The capitalists and their economists were fortified in their faith by their ignorance, and that is a wonderful fortification for some kinds of faith.

They simply observed that profits rolled in and productivity increased at a rate and on a scale never known before, and that this continued year after year. Hypnotized by the marvelous empirical phenomenon, they mistook a passing phase for a permanent condition.

This misunderstanding was widely shared. The myth of the Twenties penetrated deeply into all social strata in the United 
States and imbued even the great mass of the workers with future hopes of prosperity and security under capitalism. Those were the conditions under which the pioneer communists had to lay the foundation for a party aiming at the revolution. The confidence and illusion in the permanence of the prosperity of capitalism penetrated down into the depths of the working class itself.

The great boom of the Twenties developed under the most favorable conditions. The American sector of capitalist economy was still in its healthy prime, relying on a vast internal market of its own which extended from coast to coast and from Canada to the Gulf, and on an expanding foreign trade. All other conditions were most favorable then.

But in spite of that, it is now a matter of historical record that this great boom ended with the stockmarket crash of 1929. It is a matter of record that the crisis lasted, with some fluctuations, for ten years.

The salient facts and figures about the crisis of the Thirties are recited in our theses. They show the depth and intensity of the crisis, its horrible effects in terms of human misery, and the irreparable blows it dealt to the American capitalist system. National income was cut in half, and with it the living standards of the workers were cut in half. Unemployment reached the figure of 20 million out of a working-class population of no more than 40 million at the time.

The partial recovery, brought about in large measure by huge government expenditures, only led to a second sharp drop in 1937, a crisis within the crisis. The crisis as a whole lasted for ten solid years. And even then, a way out to the revival and increase of production and the absorption of the unemployed, was found only in the war and the colossal expenditures connected with it.

And this artificially induced recovery, which greatly expanded the productive plant of the country and the numerical force of the working class, has only deepened the contradictions and has prepared all the conditions for the explosion of another crisis, far worse than the Thirties and fraught with far more serious social implications.

So, in surveying the future prospects of American capitalism, we simply heed the counsel of realism by putting the question: If American capitalism was shaken to its foundations by the crisis of the Thirties, at a time when the world system of capitalism-and America along with it, and America especiallywas younger, richer and healthier than it is now; if this crisis lasted for ten years, and even then could not be overcome by the normal operation of economic laws; if all the basic causes 
and contradictions which brought about the crisis of the Thirties have been carried over and lodged in the new artificial war and postwar prosperity, with new ones added and old ones multiplied many times; if all this is true and nobody but a fool can deny it, for the facts are clearly to be seen-then what chance has the capitalist boom of the Forties, that we are living under now, to have a different ending than the boom of the Twenties?

Marxist realism tells us that it can be different only insofar as the crisis must go far deeper, must be far more devastating in its consequences, and must come sooner than it came in the boom of the Twenties.

The specious theory expounded by the foolishly optimistic bourgeois economists in the heyday of the capitalist boom of the Twenties, to the effect that Marx had been outwitted by American business genius, was refuted by the ten-year crisis of the Thirties-and that crushing refutation remains in the mem. ory of all.

How inexcusable, then, how absurd, how downright reactionary is the cultivation of this myth under the new conditions today!

In justice to the bourgeoisie and their ideologists it must be admitted that they, instructed by the experiences of the past, now take a far more sober and cautious position in their prog. nostications of the future. The burnt child fears the fire-that is, if he is a bourgeois economist, a businessman, and not a theoretical trifler.

The bourgeois economists and businessmen talk today far more of "boom and bust" than of boom without end. Any businessmen's economic review you may pick up at random expresses dark forebodings for the economic future. They speak quite casually - as though it is a matter of course, to be taken for granted-of an impending "shake-out" which will slow down the wheels of production and bankrupt the smaller firms which have flourished on the fringes of the boom.

At first, they referred to this process as a "shakedown," but that expressed their thoughts too truthfully. And since bourgeois economists cannot live without lying and dissimulating, they stopped talking about the "shake-down" and finally hit on the ouphemistic substitute of a "shake-out."

That sounds better but it will not be one cent cheaper.

The sole chorus of optimism, where the economic prospects of American capitalism are concerned, is that raised by the American variety of Mensheviks. And that is a thin, piping chorus of trebles and tremolos, without a bass voice in it, or a baritone, or even a first-class tenor. It is a eunuch's chorus. 
Our fundamental theses on the American Revolution do not tie themselves to the economic prospects of the next month or the next year. They deal exclusively with the long-range inevitable outcome of the present artificial prosperity. From the point of view of our theses it makes no difference whether the deepgoing crisis begins in the early spring of 1947, as many bourgeois economists are predicting; or six months later, as many others think; or even a year or two later, as is quite possible in my opinion. Our theses do not consider immediate timeschedules, but the general perspective. That is what we have to. get in mind first.

We take the position that the crisis is inherent in the situation; that it may not be escaped or avoided; and that this crisis, when it strikes in full force, will be far deeper and far more devastating than was the crisis of the Thirties. As a consequence it will open up the most grandiose revolutionary possibilities in the United States. That conception must be at the base of the policy and perspectives of our party from now on.

\section{The Transformation of the American Working Class}

I proceed from the discussion of the objective factors in the broadest sense, as our theses do, to go over to another of the most fundamental factors making for the coming American Revolution and its victory.

The American working class which confronts the next crisis will not be the disorganized and helpless mass which met the crisis of the Thirties in bewilderment and fear, and even with an element of despair. Great changes have taken place in the meantime, and all these changes redound to the advantage of the revolution.

The proletariat greatly increased in numbers with the expansion of industry during the war. Millions of Negroes, of women, and of the new generation of youth have been snatched up out of their former existence and assimilated into the processes of modern industry. Thereby, they have been transformed from a multitude of dispersed individuals into a coherent body imbued with a new sense of usefulness and power.

Most remarkable of all, the most pregnant with consequences for the future, is the truly gigantic leap which the American workers made from disorganized individual helplessness to militant trade union consciousness and organization in one brief decade. The trade union movement in the early Thirties embraced barely more than three million mem. 
bers. Today the figure stands at 15 million members of organized labor in the United States.

One can point to this fact and say that this represents a remarkable growth. But these bare figures, eloquent as they are, do not in themselves tell the whole story, the true story. For of the three million-odd members of the trade unions in the early Thirties, the great majority were composed of the thin stratum of the most skilled and privileged workers who are the most conservative in their social thinking. The great bulk of workers in the mass production industries - the most decisive section of the proletariat-were entirely without benefit of organization and had never even known the experience of it.

In spite of that-or more correctly, because of that-when these mass production workers took the road of trade union organization, with the partial revival of industry in the middle Thirties, they were not impeded by the old baggage and deadening routine of the conservative craft unions. They started from scratch with the modern form of organization - the industrial union form-and with the most militant methods of mass struggle, which reached their apex in the great wave of sitdown strikes in 1937.

The benefits these mass production workers derived from trade unionism were wrested from the employers in open struggle, and therefore were all the more firmly secured. The stability and cohesiveness of the trade union organizations created in these struggles were put to the test in the strike wave of the past year. Here we saw a clear demonstration of the great difference in the relationship of forces between the workers and the capitalists at the end of World War II from that which prevailed at the end of the First World War, a difference entirely in favor of the workers.

After the successful termination of the First World War "to make the world safe for democracy," the ruling class of America embarked on a furious reactionary campaign to break the unions, to establish the open shop and to suppress all forms of labor radicalism. In the "Palmer Red Raids" of 1919 hundreds of political meetings were broken up and thousands of radical workers were arrested, hundreds were sent to prison, whole ship-loads of foreign-born workers were deported. The newly-founded Communist Party was savagely persecuted, its leaders arrested and indicted and the party driven underground.

Simultaneously, the steel strike was broken, in part by ruthless violence and in part by the wholesale importation of strikebreakers; unions newly-formed during the war were broken up and scattered right and left; the railway shopmen's strike was defeated in 1922. American capitalism, smashing all opposition 
before it, marched confidently into the strike-less, open-shop paradise of the great boom of the Twenties.

The same thing was attempted, or at least contemplated, for the period immediately following World War II, but the result was a miserable fiasco. This time it was the organized workers who were victorious on every front.

The great industrial unions of the steel, auto, oil, packinghouse, electrical and maritime workers demonstrated their capacity to bring production to a complete stop until the employers came to terms. So great was the new-found solidarity and militancy of the workers that neither violence nor the importation of strike-breakers - the decisive factors in the defeat of the strikes following World War I-could even be attempted by the bosses.

Millions and tens of millions of workers in other industries, profiting by the example of the auto, steel, packinghouse, electrical and other strikes, and riding on the wave created by them, gained wage increases by "collective bargaining," while keeping their unions intact and even strengthening them.

Where did this marvelous labor movement come from? Who created it?

Here we must pay due acknowledgement to American capitalism. By the blind operation of its internal laws and method of operation, it has created the greatest power in the worldthe American working class. Here is where Marx takes revenge on Henry Ford. Capitalism produces many things at a rapid rate and in great quantities. But its richest contribution to the further and higher development of human civilization is the production of its own grave-digger-the organized working class.

American capitalism, as we know, could not work the miracle of boom-without-crisis. But in the period of the Twenties and Thirties, working blindly and unbeknownst to itself, it wrought some other wonders which border on the miraculous.

American capitalism took millions of bare-footed country boys from the bankrupted farms of the country; put shoes on them and marched them into the regimented ranks of sociallyoperated modern industry; wet them in the rain of the mankilling speed-up exploitation of the Twenties; dried them in the sun of the frightful crisis of the Thirties; overworked them on the assembly line, starved them on the bread-line, mistreated and abused them; and finally succeeded in pounding them into a coherent body which emerged as a section of the most pewerful and militant trade union movement the world has ever known.

American capitalism took hundreds of thousands of Negroes from the South, and exploiting their ignorance, and their poverty, and their fears, and their individual helplessness, herded 
them into the steel mills as strike-breakers in the steel strike of 1919. And in the brief space of one generation, by its mistreatment, abuse and exploitation of these innocent and ignorant Negro strike-breakers, this same capitalism succeeded in transforming them and their sons into one of the most militant and reliable detachments of the great victorious steel strike of 1946.

This same capitalism took tens of thousands and hundreds of thousands of prejudiced hill-billies from the South, many of them members and sympathizers of the Ku Klux Klan; and thinking to use them, with their ignorance and their prejudices, as a barrier against unionism, sucked them into the auto and rubber factories of Detroit, Akron and other industrial centers. There it sweated them, humiliated them and drove and exploited them until it finally changed them and made new men out of them. In that harsh school the imported southerners learned to exchange the insignia of the K.K.K. for the union button of the C.I.O., and to turn the Klansman's fiery cross into a bonfire to warm pickets at the factory gate.

You won't find $\mathrm{Ku}$ Kluxers or Black Legionnaires in the auto and rubber factories today-or at any rate, not many of them. But there is a mighty sight of first-class shop stewards and picket captains who originally came down out of the hills and up from the bayous of the backward South at the summons of American capitalism.

The American working class covered the great distance from atomization, from non-existence as an organized force, to trade union consciousness and organization, in one gigantic leap, in one brief decade.

What grandiose perspectives this achievement opens up for the future! What are the limits to the future possibilities and powers of this remarkable class? There are no limits. All things are possible; and all things that are necessary will be achieved.

If someone had predicted in 1932, at the depths of the crisis, that in ten-years' time 10 million new workers who had never known unionism would organize themselves into industrial unions of the most modern type and demonstrate their ability to force the absentee owners of the steel and auto and rubber and other mass production industries to come to terms and not even to dare to attempt to break the strikes-the skeptics would have said: "This is fantasy. This is ultra-left radicalism."

But it happened just the same.

The American workers do not always move when impatient revolutionists call them, as many of us have learned to our sorrow. But they do move when they are ready, and then they move massively. 
Industrial unionism is not a new idea. It was projected long before it found its realization on a mass scale in America, and the pioneers of industrial unionism in America suffered many disappointments. In 1930 the IWW dolefully observed its 25th Anniversary. At the end of a quarter of a century, the organization which had proclaimed the program of indus. trial unionism 25 years earlier was completely defeated, a hollow shell comprising far less members than it had started with in the bright year of promise, 1905, under a great galaxy of leaders. Industrial unionism seemed to be a defeated program in 1930. But only ten years later the majority of the most important basic industries were completely organized in industrial unions under a new name.

The workers did not move when the IWW called them in 1905. They didn't move when many of us called them later than that. But they moved when they were ready and when conditions were mature for it, and then they moved on a scale and at a speed scarcely dreamed of by the pioneers of industrial unionism.

The scale of the difference is remarkable. Bill Haywood, the great captain of the IWW-I love to mention his nameused to dream and speak in his intimate circle of the goal of a "million members" in the IWW. As a matter of fact, the organization never had more than 100,000 at any one time in all its history, and most of the time only a fraction of that number. The great strikes of the IWW which took place in its heyday, those great pioneer battles which heralded and blazed the way for, the CIO-Lawrence, Akron, Paterson, McKees Rocks, the lumber strikes in the Northwest-they never involved more than 10 to 20 thousand workers at any one time.

But in 1946 nearly two million workers of the CIO, with only a few years of trade union experience behind them, were on strike at one time!

These comparative figures show not growth, not simply progress, but a veritable transformation of the class. And what has been seen up to now are only the preliminary movements, the promise and the assurance of far greater movements to come. Next in order-and not far away-comes the political awakening of the American workers. That will be at the same pace and on the same scale, if not greater. The American workers will learn politics as they learned trade unionism- "from an abridged dictionary." They will take the road of independent political action with hurricane speed and power.

That will be a great day for the future of humanity, for the American workers will not stop half way. The American 
workers will not stop at reformism, except perhaps to tip their hats to it. Once fairly started, they will go the whole way.

He who doubts the socialist revolution in Ameriea does not believe in the survival of human civilization, for there is no other way to save it. And there is no other power that can save it but this all-mighty working class of the United States.

The young generation entering the revolutionary movement today, with the goal of socialism shining bright in their far. reaching vision, come at a good time. A lot of pioneer work has been done. Many obstacles have been cleared out of the road. Many conditions for success have matured.

The young generation coming to us today comes to a party that foresees the future and prepares for it. They come to a great party. with a glorious record and a stainless banner, a party that has already been prepared for them and awaits their enlistment. They come to a strong party, firmly built on the granite rock of Marxism. This party will serve them well, and is worthy of their undivided allegiance.

This 12th Convention coincides with the 18th Anniversary of the party. The experience and tradition of the party are the capital of the new generation. The work of many people for two decades has not been done in vain. And, besides that, the new recruits can find in a realistic examination of the objective facts many assurances that the course of development is working mightily in favor of the realization of their ideal.

Our economic analysis has shown that the present boom of American capitalism is heading directly at a rapid pace toward a crisis; and this will be a profound social crisis which can lead, in its further development, to an objectively revolutionary. situation.

Our analysis of the labor movement has shown that the workers have already demonstrated the capacity to move mass. ively and rapidly forward in the field of trade unionism; and we have every right to confidence that they will move even more massively and with even greater speed on the political field in the days to come.

The objective prerequisites for the social revolution in America will not be lacking. Capitalism itself will provide them. The manpower of the revolution will not be lacking either. The many-millioned masses of the organized workers of America will provide this manpower. It is already partly assembled and partly ready.

The rest is our part. Our part is to build up this party which believes in the unlimited power and resources of the American workers; and believes no less in its own capacity to organize and lead them to storm and victory. 


\section{Other Books and Pamphlets by James P. Cannon}

THE HISTORY OF AMERICAN TROTSKYISM

280 pp. Cloth $\$ 2.00$

Paper 1.00

THE STRUGGLE FOR A PROLETARIAN PARTY 320 pp. Cloth 2.00 Paper 1.50

THE RUSSIAN REVOLUTION 32 pp. $\quad .10$ THE END OF THE COMINTERN 36 pp. $\quad .10$ MEMORIAL ADDRESS

"TO THE MEMORY OF THE OLD MAN"._. 16 pp. .05 Order from

PIONEER

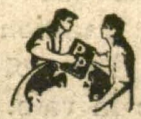

PUBLISHERS

116 University Place New York 3, N. Y.

Subserbe to

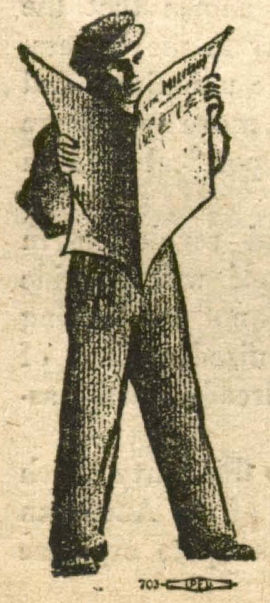

THE MILITANT

A WEEKLY NEWSPAPER

Published in the Interests of the Working People

The only newspaper in this country that tells the truth about labor's struggles for a better world 50 for 6 months - $\$ 1$ for 1 year

\section{THE MILITANT}

116 University Place New York 3, N. Y. 